\title{
The termicidal effect of some plant material on some selected wood species
}

\author{
S. A. ADEDUNTAN \\ Department of Forestry and Wood Technology, Federal University of Technology, Akure. Nigeria. \\ E-mail: niyi_gbenga@yahoo.co.uk; www.futa,edu.ng; GSM: +2348063480727
}

\begin{abstract}
The resistance of some wood species treated with plant extracts against termite attack was investigated in this study. Three wood species were used for the study (Ceiba petandra (Araba), Gmelina arborea and Triplochiton scleroxylon (obeche)) they were treated with five different plant extract (Allium sativum extract, Datura stamonium extract, Jatropha curcus oil, Musa acuminata sucker extracts and the Chrysophyllum albidum extract). The treated wood samples were exposed to termite infestation for a period of 12 weeks at the timber grave yard. Before exposure, the wood samples were oven dried for 24 hours at $105{ }^{\circ} \mathrm{C}$, cold soaked for 24 hours and condition for 72 hours. The visual observations of the wood were recorded bi-weekly for 12 weeks. All the plant extracts were in $100 \%$ concentration except $D$. stramonium which had a concentration of $0.058 \%$. The result showed that $C$. petandra had the highest mean percentage absorption for $D$. stramonium water extracts with $89.06 \%$ follow by $M$. acuminata extract with $58 \%$, while $C$. albidum extracts had the least absorption. The weight loss was significantly lower in $G$. arborea wood. It was observed that $D$. stramonium water extracts and $J$. curcas were found effective for wood preservation in other to elongate the life span of wood material.

() 2014 International Formulae Group. All rights reserved.
\end{abstract}

Keywords: Allium sativum, Datura stamonium, Jatropha curcus, infestation, extracts.

\section{INTRODUCTION}

Throughout the course of history, wood has remained one of the most important renewable natural resources available to mankind. It is a natural, cellular, renewable resource has excellent strength to weight properties, a relatively low price and it easily produced composite material of botanical origin possesses unique structural and chemical characteristics that render it desirable for broad variety of end users (Hingston et al., 2001). On the other hand, one of the major objections of the use of wood for many purposes is of course the question of its long-term resistance to the natural processes of degradation (Yalinkilic, 2000). Wood preservatives are toxic materials used for protecting wood in service against deteriorating agents like termites, fungi, etc. (Ifebueme, 1977).

Termites are the most troublesome pest of plants, trees and wooden structures. They severely damage agricultural crops and urban infrastructure. There are about 2,500 species of termites in the world and only $10 \%$ have pest status. Termites can attack plants at any stage of development from the seed to the mature plant. They are social insects that live 
together as a colony in a nest. Colony members belong to one of three interdependent groups with specialised form and function known as castes. The three basic castes present in the colony are workers, soldiers and reproductive forms. Workers and soldiers are wingless, sterile and blind. Workers construct the distinctive shelter tubes and collect food to feed the young and other members of the colony. The primary function of the soldiers is to defend the colony, usually against ants, which are their main enemies. The reproductive caste is usually referred to as the king and queen. They are responsible for the production of fertilised eggs for the colony and of specialized chemicals (hormones) important for managing the inhabitants of the colony. Mature colonies produce winged reproductive forms or alates at certain times of the year. After the dispersal flight, the alates attempt to find mates and found new colonies (Horwood and Eldridge, 2005). Termites are most successful of all the social insects because colony members are long lived and because they utilize cellulose as food source. They depend entirely over wood, either living or dead, or the woody tissue of plants, intact or partially decayed and also in the form of humus and dried animal dung. Termites are attracted to odours of wood decay fungi that make the wood easy to penetrate (Roger et al., 2006).

The demand for wood by the populace for constructional purpose is very high thereby having serious effect on the forest. Wood is used for constructional purpose like furniture making, building of wooden fabricated houses, etc.

There is a need to preserve wood in service to increase its durability and to also preserve it against wood deteriorating agents. This also helps reducing the pressure on the forest.

These preservatives are classified as Tar oil preservative and water borne preservative and organic solvent base preservatives. Oil borne preservative treatment are generally recognized as imparting superior dimension stability to treated wood products when compared to water borne preservative treatments because of the none polar nature and natural water repellence of oil borne system. Oil borne preservative treatments are also generally recognized as having less effect on mechanical prosperities than to water borne treatment because they do not react with the wood cell wall material.

There is an increasing awareness of the potential of natural products, which may lead to the development of much-needed new preservatives (Tagboto et al., 2001). Thus there is the need to further educate people about the benefits of the alternative preservatives, which are environmental friendly, cheap and available to the users. Consequently, various environmentally friendly treatments or naturally durable plant species are being evaluated.

This study therefore, evaluate the extract from Allium sativum (bulb), Musa acuminata (sucker), Datura stramonium (fruits), Jatropha curcas (seed), Chysophyllum albidum (seed) on Gmelina arborea, Ceiba petandra, and Triplochiton scleroxylon wood samples as they are highly susceptible to termites attack.

\section{MATERIALS AND METHODS \\ Study area}

The study was carried out at the departmental temporary termitarium located opposite University central mosque Obanla in Federal University of Technology Akure, FUTA (Lat. $7^{\circ} 17^{\prime} \mathrm{N}$, Long $5^{\circ} 10^{\prime} \mathrm{E}$ ). This zone lies in the tropical rainforest zone of Nigeria with mean annual temperature of $20{ }^{\circ} \mathrm{C}$; elevation, $350 \mathrm{~m}$; relative humidity $85-100 \%$ during the rainy season and $60 \%$ during the harmattan period. Akure lies within the tropical rainforest zone of Nigeria, with mean annual temperature of about $27^{\circ} \mathrm{C}\left(\min 19{ }^{\circ} \mathrm{C}\right.$ and maximum $34{ }^{\circ} \mathrm{C}$ ). The soil of the study area is classified as ferruginous tropical soil (Alfisol) on crystalline rock of basement complex. The soil belongs to the Egbeda 
series (Smyth and Montgomery, 1962). The soil is a characteristic red laterite rich in Iron and aluminum which favours termite activity. The soil fairly medium drained but with a possibility of being water logged during the rainy season.

\section{Wood sample preparation}

The wood samples used in this study were gotten from sawmill around Akure metropolis (from a matured trees) of various timber species. The wood samples was then cut into small piece with dimension of $20 \mathrm{~mm}$ by $20 \mathrm{~mm}$ by $60 \mathrm{~mm}$ (breath by width by length) with a circular saw machine and the wood sample sanded using fine sanding paper to remove / eliminate rough edges. Since only three different species of wood were used (Gmelina arborea, Ceiba petandra, Triplochiton scleroxylon) but with three (3) replicate and five different plant extracts. The wood samples were labelled accordingly for easy recognition and differentiation.

The wood samples were oven dried for 24 hours at $105^{\circ} \mathrm{C}$; the samples were weighed after oven drying as $\mathrm{T}_{1}$. The wood samples were soaked into the already prepared plant extracts for 24 hours (cold soaking) and were removed and drained for few hours on the wire mesh to remove excess extracts, the samples were weighed again as $T_{2}$, after weighing the wood samples were leaved on the wire mesh for 72 hours for conditioning, after 72 hours the wood samples were weighed as $\mathrm{T}_{3}$. All the weighing was done by the use of the weighing balance.

The penetration was measured by slicing some treated wood samples of different species with different plant extracts into two and was measured using vernier calliper.

The graveyard was cleared and cleaned the wood samples was taken to the graveyard and were laid on the surface of the ground and leave for a period of 12 weeks, after 12 weeks the wood samples were collected and weighed as $\mathrm{T}_{4}$.
Method of preparing the preservatives Extraction of oil from Chrysophyllum albidum

The seed of white star apple was gotten from Akure metropolis. The seeds were dried and the cotyledon removed (the cotyledon is white in colour when fresh and brown in colour after drying); the dried seed was ground into powder form with grinding machine.

Extraction was carried out using soxhlet apparatus and n-hexane was the solvent used to extract the oil.

\section{Extraction of oil from Jatropha curcas seed}

The seed was picked around Akure metropolis and de-shell; the cotyledon was sun-dried and ground. The pulverized seed was weighed and put inside the oven for 10 minutes. It was removed from the oven and pressed with hydraulic press to remove the oil. The oil gotten was used as wood preservatives.

\section{Extraction of Allium sativum (garlic)}

The bulb of garlic was ground with grinding machine without adding any water, the ground garlic was put inside a woven plane cloth in form of a bag and pressed with hydraulic press to remove the extract. The garlic extract was used to preserve the wood samples.

\section{Extraction of sap from the sucker of Musa acuminata}

The sucker of $M$. acuminata was uprooted and cut into small pieces and pressed with hydraulic press to remove the extracts. The extract was used as wood preservative to preserve wood against termites infestation.

\section{Water extraction of Datura stramonium}

Two hundred grams of $D$. stramonium fruits were sliced and soaked in 4 litres of water for 12 hours, after 12 hours, the mixture were sieved. The water extract was used as preservatives against termites attack. 


\section{Treatment method}

The wood samples were treated following the procedure of ANSI/ASTMD 1413-1976/10PP435-7. The wood samples was marked with a water proof marker and dried, and sample oven dried at $105{ }^{\circ} \mathrm{C}$ for 24 hours before applying plant extractives. The samples were treated with the plant extractives in cold concentration form for 24 hours.

The treated wood samples were drained on a wire mesh and then weighed to determine the absorption and retention of preservatives.

\section{Absorption test}

The wood samples were marked with water proof marker and were dried to constant weight in an oven for 24 hours.

The wood samples were weighed before the experiment $\left(T_{1}\right)$ i.e. the initial weight or the weight of the untreated wood samples. After the wood samples was treated with preservatives, it was reweighed again $\mathrm{T}_{2}$. Absorption \% $=100\left(\mathrm{~T}_{2}-\mathrm{T}_{1}\right) / \mathrm{T}_{1}$

Where $\mathrm{T}_{2}=$ Treated weight

$$
\mathrm{T}_{1}=\text { dry weight }
$$

\section{Retention test}

The retention of the preservatives was calculated according to ANSI/ASTM D281 (1979) using this formula:

Retention $\left(\mathrm{g} / \mathrm{cm}^{3}\right)=10(\mathrm{GC} / \mathrm{V})$

Where:

$\mathrm{G}=\mathrm{T}_{2}-\mathrm{T}_{1}$, treated weigh- initial weight

$\mathrm{C}=$ grams of preservatives in $100 \mathrm{~g}$ of treated solutions

$\mathrm{V}=$ volume of samples $(\mathrm{L} \times \mathrm{B} \times \mathrm{W}) \mathrm{cm}^{3}$

\section{Conditioning of the treated samples}

The treated wood samples were conditioned before further test was carried out on it. The treated wood samples were placed on wire mesh and they were exposed to open laboratory condition for 72 hours. Individual treated wood samples were reweighed $\left(\mathrm{T}_{3}\right)$.

\section{Field test}

The field test was adopted from ANSI/AWPA (1988) D1413-76. The field test was carried out at the Departmental graveyard. The treated wood samples were laid on the surface of the ground within the graveyard. Samples were checked bi-weekly by visual observation of wood samples on the field for the rate of termite attack.

\section{Extent of attack and evaluation}

The visual observation and evaluation of wood samples was based on the standard American Society of Testing Materials ASTM D 3345-74 (1974).

Visual rating will be calculated as follows:

$10=$ Sound surface nibbles permitted

$9=$ Light attack

$7=$ Moderate attack penetration

4 = Heavy attack, $40 \%$ of the wood crosssection eaten up by termites

$0=$ Failure, over $50 \%$ of the wood crosssection eaten up by termites

At the end of the experiment, the wood samples were withdrawn and weighed $\left(\mathrm{T}_{4)}\right.$.

Calculation of weight losses of wood in percentage

Weight loss due to termites attack:

Weight loss in $\%=100\left(\mathrm{~T}_{3}-\mathrm{T}_{4}\right) / \mathrm{T}_{3}$

$\mathrm{T}_{3}=$ conditioned weight after treatment

$\mathrm{T}_{4}=$ weight of conditioned wood samples after exposure to termites attack.

\section{RESULTS}

Percentage absorption in the three wood species

The result of the absorption test is presented in Table 1. The preservatives: $D$. stramonium extracts, oil of $C$. albidum seed, oil of $J$. curcas seed, M. acuminata sucker extract, and A. sativum extract shows an increase in the original weight of wood after cold soaking. The relative absorption test showed that all cellulosic materials (wood) can absorb plant extracts, oil and water preservatives. 
The effects of the plant material (preservatives) on absorption by the wood species were significantly different (Table 2). The percentage mean absorption of the $A$. sativum extracts, D. stramonium, J. curcas oil, M. acuminata, and C. albidum oil in $C$. petandra wood is as follows: $34.19 \%$, $89.60 \%, 30 \%, 58 \%$, and $28 \%$ respectively. This shows that D. stramonium has the highest mean absorption while the least was recorded in $C$. albidum oil extract. The absorption by $C$. petandra wood shows that $D$. stamonium and $M$. acuminata preservatives are not significantly $(\mathrm{P} \geq 0.05)$ different (Table 2). The mean percentage absorption of preservatives of $A$. sativum, $D$. stramonium, $J$. curcas, M. acuminata, $C$. albidum in $G$. arborea wood, were recorded as $13 \%, 28 \%$, $7.6 \%, 21 \%$, and $9.06 \%$ respectively. Absorption of D. stramonium extractive by $G$. arborea wood was significantly ( $\leq \leq 0.05$ ) higher than other preservatives while $J$. caucus oil was significantly $(\mathrm{p} \leq 0.05)$ lower. Mean percentage absorption of preservatives by $T$. scleroxylon wood are $33 \%, 62 \%, 25 \%$, $53 \%$, and $21 \%$ for A. sativum, D. stramonium, J. curcas oil, M. acuminata, and C. albidum oil respectively. Like in other wood species, the highest mean percentage absorption was recorded in D. stramonium extractive followed by $M$. acuminata, A. sativum, J. curcas oil and lastly $C$. albidum oil. This study shows that $D$. stramonium and $M$. acuminata were well absorbed into the cell lumen of the wood samples. It was also observed that the wood species with lowest absorption was found to be G. arborea.

\section{Preservative retention by the wood species}

The result of the effect of the retention of the preservatives by the wood samples is shown in Table 1. Retention is the quantity of active ingredients of the preservatives retained in the wood; this is expressed as the weight of the ingredients to volume of the wood in $\mathrm{g} / \mathrm{cm}^{3}$. The mean retention value by $C$. petandra wood samples from extract of $A$. sativum, D. stramonium, J. curcas, $M$. acuminata and C. albidum oil were 112.67 $\mathrm{g} / \mathrm{cm}^{3}, 0.158 \mathrm{~g} / \mathrm{cm}^{3}, 98.610 \mathrm{~g} / \mathrm{cm}^{3}, 195.83$ $\mathrm{g} / \mathrm{cm}^{3}$ and $90 \mathrm{~g} / \mathrm{cm}$ respectively. Likewise, the mean retention values by $G$. arborea wood for extract of A. sativum, D. stramonium, $J$. curcas, M. acuminata, C. albidum were 68.05 $\mathrm{g} / \mathrm{cm}^{3}, \quad 0.803 \mathrm{~g} / \mathrm{cm}^{3}, 38.88 \mathrm{~g} / \mathrm{cm}^{3}, 106.94$ $\mathrm{g} / \mathrm{cm}^{3}$, and $44.44 \mathrm{~g} / \mathrm{cm}^{3}$ respectively, extract from $M$. acuminata has the highest mean retention value by $G$. arborea wood while the lowest was recorded from the extract of $D$. stramonium.

\section{Results of percentage weight loss}

The effect of exposing treated wood samples was significantly different (Table 1). Likewise there are significant differences in weight loss by the wood species. Table 2 shows the result of weight loss at the end of 12 weeks exposure all the control samples were totally destroyed by termites. The weight loss by $C$. petandra was significantly higher $(\mathrm{P} \leq 0.05)$ than other wood species; most of all the $C$. petandra wood samples were all destroyed within the exposure period despite the preservatives treatment used. G. arborea wood samples treated with the preservatives were the least attack by the termites. $G$. arborea treated with A. sativum extracts was the least attacked by termites with $0.25 \%$ weight loss follow by the samples treated with D. stramonium with $1.81 \%$ and the weight loss values for J. curcas, M. acuminata and C. albidum were $4.44 \%, 28.06 \%, 69.17 \%$ respectively.

Attack was discovered after the $3^{\text {rd }}$ week on the control wood samples and before the end of 12 weeks all the control wood samples were completely destroyed by the termites. It was also observed that $C$. petandra wood species treated with $M$. acuminata sap extract was the first species to be attacked by termites.

\section{Depth of penetration}

After soaking the wood in preservatives for 24 hours the depth of penetration varied from species to species. J. curcas treated 
wood samples shows that $C$. petandra, $G$. arborea, T. scleroxylon had penetration depth values of $0.2 \mathrm{~cm}, 0.4 \mathrm{~cm}$, and $0.1 \mathrm{~cm}$ respectively, while $C$. petandra, $G$. arborea and T. scleroxylon wood species treated with A. sativum extract have depth of penetration values of $0.2 \mathrm{~cm}, 0.1 \mathrm{~cm}$ and $0.2 \mathrm{~cm}$ respectively.

\section{Visual observation after 12 weeks}

The results of the visual observation during the period of 12 weeks exposure to the termite attack were presented in Table 3 . It shows that for the first 2 weeks of exposure there was no termite attack on any of the wood samples. At 10 weeks of exposure termite had destroyed all the $C$. petandra wood samples, while the most resistant to termite attack after 12 weeks of exposure to termite in the timber graveyard was $G$. arborea wood samples. However, massive attack took place after the $8^{\text {th }}$ weeks of exposure which could be attributed to the heavy rain falls during the periods of experimentation which may in turn have caused leaching out of the preservatives from the wood thereby making the preservative chemicals in the wood samples to be weakened. As earlier stated there was no attack on the wood samples until the first two weeks. This may be as a result of the odour of the garlic extract, because it is believed that the odour of garlic repels insects and termites. By the $12^{\text {th }}$ weeks, all the $C$. petandra had been eaten by the termites.

Table 1: Analysis of variance (ANOVA) showing the influence of plat material on percentage Absorption, Retention and Weight Loss by different wood species.

\begin{tabular}{lcccccc}
\hline Factor & Source & $\begin{array}{c}\text { Sum of } \\
\text { squares }\end{array}$ & $\begin{array}{c}\text { Degree of } \\
\text { freedom }\end{array}$ & $\begin{array}{c}\text { Mean } \\
\text { square }\end{array}$ & F & Sig \\
\hline Percentage & & & & & & \\
absorption & Treatment & 10896.15 & 4 & 2724.04 & 39.79 & $0.000^{*}$ \\
& Species & 8326.16 & 2 & 4163.08 & 60.81 & $0.000^{*}$ \\
& Error & 2601.62 & 38 & 68.46 & & \\
& Total & 21823.93 & 44 & & & $0.000^{*}$ \\
\hline Retention by & Treatment & 123527.68 & 4 & 30881.92 & 102.51 & $0.000^{*}$ \\
different & Species & 19917.08 & 2 & 9958.54 & 33.06 & \\
wood species & Error & 11447.39 & 38 & 301.25 & & 0.003 \\
& Total & 154892.16 & 44 & & & 0.000 \\
\hline Percentage & Treatment & 12474.94 & 4 & 3118.74 & 4.98 & \\
weight loss & Species & 46511.65 & 2 & 23255.83 & 37.15 & \\
& Error & 23789.66 & 38 & 626.84 & & \\
\hline${ }^{*}$ Sigificanty & Total & 82776.25 & 44 & & & \\
\hline
\end{tabular}

\footnotetext{
"Significantly different at $(\mathrm{p} \leq 0.05)$.
} 
S. A. ADEDUNTAN / Int. J. Biol. Chem. Sci. 9(2): 986-995, 2015

Table 2: Showing the follow up test for the percentage (\%) absorption, depth of penetration, retention and weight loss.

\begin{tabular}{|c|c|c|c|c|c|}
\hline Plant Materials & Wood species & Absorption (\%) & Depth of penetration $(\mathrm{cm})$ & Retention $\left(\mathrm{kg} / \mathrm{m}^{3}\right)$ & Weight loss (\%) \\
\hline \multirow{4}{*}{ A. sativum } & C. petandra & $34.19 \pm 1.84^{\mathrm{a}}$ & 0.2 & $112.67 \pm 3.92^{\mathrm{c}}$ & $100.00 \pm 0.00^{\mathrm{a}}$ \\
\hline & G. arborea & $13.38 \pm 1.14^{\mathrm{a}}$ & 0.1 & $68.05 \pm 2.40^{\mathrm{a}}$ & $0.25 \pm 0.42^{\mathrm{a}}$ \\
\hline & Triplochiton & $33.95 \pm 4.08^{\mathrm{b}}$ & 0.2 & $105.56 \pm 2.40^{\mathrm{b}}$ & $100.00 \pm 0.00^{\mathrm{b}}$ \\
\hline & Control & 0.00 & & 0.00 & $100.00^{\mathrm{b}}$ \\
\hline \multirow[t]{4}{*}{ D. stamonium } & C. petandra & $89.60 \pm 5.7^{\mathrm{c}}$ & 0.4 & $0.158 \pm 0.14^{\mathrm{c}}$ & $100.00 \pm 0.00^{\mathrm{b}}$ \\
\hline & G. arborea & $28.44 \pm 5.08^{\mathrm{a}}$ & 0.1 & $0.803 \pm 0.07^{\mathrm{a}}$ & $1.81 \pm 0.59^{\mathrm{a}}$ \\
\hline & T. scleroxylon & $62.63 \pm 7.0^{\mathrm{b}}$ & 0.1 & $0.12 \pm 0.37^{\mathrm{b}}$ & $44.24 \pm 49.84^{\mathrm{b}}$ \\
\hline & Control & 0.00 & 0.00 & 0.00 & $100 \pm 0.00^{\mathrm{b}}$ \\
\hline \multirow[t]{4}{*}{ J. curcas seed } & C. petandra & $30.26 \pm 1.92^{\mathrm{b}}$ & 0.2 & $98.610 \pm 2.40^{\mathrm{b}}$ & $100.00 \pm 0.00^{\mathrm{b}}$ \\
\hline & G. arborea & $7.60 \pm 0.35^{\mathrm{a}}$ & 0.4 & $38.88 \pm 2.40^{\mathrm{a}}$ & $4.44 \pm 7.69^{\mathrm{a}}$ \\
\hline & T. scleroxylon & $25.76 \pm 0.92^{\mathrm{b}}$ & 0.1 & $100.00 \pm 8.33^{\mathrm{b}}$ & $100.00 \pm 0.00^{\mathrm{b}}$ \\
\hline & Control & 0.00 & 0.00 & 0.00 & $100 \pm 0.00^{\mathrm{b}}$ \\
\hline \multirow[t]{4}{*}{ Musa sap } & C. petandra & $58.54 \pm 2.44^{\mathrm{b}}$ & 0.5 & $195.83 \pm 0.00^{\mathrm{b}}$ & $100.00 \pm 0.00^{\mathrm{b}}$ \\
\hline & G. arborea & $21.91 \pm 5.15^{\mathrm{a}}$ & 0.3 & $106.94 \pm 16.83^{\mathrm{a}}$ & $28.06 \pm 32.7^{\mathrm{a}}$ \\
\hline & T. scleroxylon & $53.90 \pm 10.33^{b}$ & 0.2 & $187.50 \pm 30.04^{\mathrm{b}}$ & $100 \pm 0.00^{\mathrm{b}}$ \\
\hline & Control & 0.00 & 0.00 & 0.00 & $100 \pm 0.00^{\mathrm{b}}$ \\
\hline \multirow[t]{4}{*}{ C. albidum } & C. petandra & $28.71 \pm 0.59^{c}$ & 0.5 & $90.27 \pm 4.81^{\mathrm{c}}$ & $100.00 \pm 0.00^{\mathrm{a}}$ \\
\hline & G. arborea & $9.06 \pm 1.00^{\mathrm{a}}$ & 0.2 & $44.44 \pm 4.81^{\mathrm{a}}$ & $69.17 \pm 53.4^{\mathrm{a}}$ \\
\hline & T. scleroxylon & $21.93 \pm 4.15^{\mathrm{b}}$ & 0.1 & $68.05 \pm 12.74^{\mathrm{b}}$ & $100.00 \pm 0.00^{\mathrm{a}}$ \\
\hline & Control & 0.00 & 0.00 & 0.00 & $100 \pm 0.00^{\mathrm{a}}$ \\
\hline
\end{tabular}


S. A. ADEDUNTAN / Int. J. Biol. Chem. Sci. 9(2): 986-995, 2015

Table 3: The visual observation for 12 weeks.

\begin{tabular}{lccccccc}
\hline Plant materials & Wood species & 2 weeks & 4 weeks & 6 weeks & 8 weeks & 10 weeks & 12 weeks \\
\hline A. sativum & C. petandra & 10 & 10 & 7 & 4 & 0 & 0 \\
& G. arborea & 10 & 10 & 10 & 10 & 9 & 9 \\
& T. scleroxylon & 10 & 9 & 9 & 7 & 4 & 0 \\
\hline D. stramonium & C. petandra & 10 & 10 & 7 & 4 & 4 & 0 \\
& G. arborea & 10 & 10 & 10 & 10 & 9 & 9 \\
& T. scleroxylon & 10 & 9 & 9 & 7 & 7 & 4 \\
\hline J. curcas & C. petandra & 10 & 10 & 7 & 4 & 4 & 0 \\
& G. arborea & 10 & 10 & 10 & 10 & 9 & 9 \\
& T. scleroxylon & 10 & 9 & 9 & 7 & 4 & 0 \\
\hline M. acuminata & C. petandra & 10 & 9 & 7 & 4 & 0 & 0 \\
& G. arborea & 10 & 10 & 10 & 7 & 4 & 4 \\
& T. scleroxylon & 10 & 7 & 4 & 4 & 0 & 0 \\
\hline C. albidum & C. petandra & 10 & 9 & 7 & 4 & 0 & 0 \\
& G. arborea & 10 & 9 & 7 & 4 & 4 & 0 \\
& T. scleroxylon & 10 & 7 & 4 & 4 & 0 & 0 \\
\hline Control & C. petandra & 10 & 7 & 4 & 0 & 0 & 0 \\
& G. arborea & 10 & 9 & 7 & 4 & 0 & 0 \\
& T. scleroxylon & 10 & 7 & 4 & 4 & 0 & 0 \\
\hline
\end{tabular}

Control is untreated wood sample of each species. 


\section{DISCUSSION}

The mean percentage absorption of preservative by the wood samples shows that all the preservatives were well absorbed by cellulose materials within 24 hours of cold soaking. The mean absorption of $D$. stramonium by $C$. petandra was significantly higher than all other preservatives, followed by $M$. acuminata and $A$. sativum, J. curcas and $C$. albidum extract. The absorption of $D$. stramonium and $M$. acuminata preservatives was recorded to be the highest, this could be because they were water base preservatives which is in agreement with ASTM (1987) which stated that absorption of water soluble preservatives is higher than that of oil base. This is because water fills the air space in the wood. Likewise differences in the level of absorption among the preservatives could be due to the cell structure of the wood species, as reported by Dinwodie (1981). Viscosity is a function of absorption by the wood. The more viscous a preservative is, the lower the flow per unit time and the less the absorption especially for non-pressure treatment method. Absorption could be enhanced by heating the preservative chemicals or further dilution with solvent as in case of oil borne preservatives (Owoyemi, 2000).

The mean absorption of $J$. curcas extract by $C$. petandra was $30 \%$, this is similar to the work of Wenlong et al. (1997) who reported that oil preservatives exhibit a lot of influence on the absorption per unit volume of wood preservatives. However, the result of this work shows higher value than the work of Adeyemo (1995), who reported mean absorption value of $22 \%$. This could be as a result of variation in wood structure and age of the tree species before felling for utilization.

The mean absorption by $G$. arborea is significantly higher in $D$. stramonium extract than other plant materials used as preservative.

The absorption of plant materials ( $D$. stramonium and $M$. acuminata) by $T$. scleroxylon was significantly high. However, the treated T. scleroxylon with D. Stramonium gives high resistance to termite attack while those treated with $M$. acuminata were susceptible to termite attack. Thus, it does not follow that the higher the absorption and the penetration of extractives, the higher the resistance to attack by biodegradation agent (termite). What determines the resistance of attack by the treated wood could be the active ingredient in preservative chemical.

The result presented in Table 2 shows that retention of preservative chemical by wood species was significantly different. This is similar to the observation of (Schultz et al., 2005) who reported that wood exhibit variation in absorption and retention of chemical preservatives when treated. The variation in the preservatives retention, according to them could affect the life span of individual wood products. This implies that the amount of preservative retained in the cellulose materials varied according to anatomical structures of the various wood species. Likewise Adeduntan and Olusola (2008) concluded that the amount of preservatives retained in the cellulosic materials varied according to the anatomical structures of wood species. The preservative retention by $G$. arborea was not significantly different from all the five preservatives used. There are significant differences in the $\mathrm{T}$. scleroxylon wood treated with different preservatives chemicals derived from various plant materials.

The result of $C$. petandra treated with $M$. acuminata extract show significantly higher penetration with high susceptibility to termite attack which is contrary to the observation of Diana (2003) who reported that the depth of penetration of preservative is among the factors that determine the effectiveness of preservatives on wood. $T$. scleroxylon treated with D. stamonium seed extract has the least penetration which shows very high resistance to termite attack. This implies that D. stamonium extract could be used as preservative against wood deteriorating termite.

\section{Conclusion}

All wood species can absorb and retain both oil and water borne preservatives. 
However, the rate and depth of absorption was generally higher in water born preservatives than oil born preservative.

It was also observed that the percentage of absorption or depth of preservation does not indicate the effectiveness of preservatives but the active ingredient that such preservative chemical contained.

From the results of this study, it could be recommended that $J$. curcas and $D$. stamonium should be adopted as preservative treatments in order to prolong the life span of our wood and wood product against termite attack.

\section{REFERENCES}

Adeduntan SA, Olusola JA. 2008. Termicidal effects of creosote oil and spent engine Oil on some treated hardwood species, Nigeria Journal of Forestry, 38(1): 1-8

Adeyemo TI. 1995. Evaluation of creosote and aldex as termite control on preservatives for some selected wood species. Unpublished B. Agric. Tech. Thesis Department of Forestry and Wood Technology, Federal University of Technology Akure Nigeria, 51-86.

ASTM. 1987. Standard method for evaluating preservatives. America Standard for Testing Materials ASTM DB 345-74, 926-929

American Society for Testing and Materials. 1974. Standard method of evaluation of wood And other cellulosic materials for resistance to termites. D 3345-74. Annual Book of ASTM Standards, 926-929.

America Society for Testing Materials. 1979. Standard method of testing wood preservatives By laboratory soil block cultures. D 1413-76. Annual Book of ASTM standard, 250-458

Dinwodie Desch JM. 1981. Timber its Nature Behaviour. Van Nostrand Reinhold Co. Ltd: Berhshire, England; 170.

Hingston AJ, Collins CD, Murphy RJ, Lester JN. 2001. Leaching of chromated copper
Arsenate wood preservatives. Rev. Environ. Pollute, 111(1): 53-56.

Horwood MA, Eldridge RH. 2005. Termites in New South Wales. Forest Resources Research, 21 Technical Publications No. 21. Available online at: http://www. forest.nsw.gov.au/research/pdfs/termites/ Termites-Biology.pdf

Ifebueme SC. 1977. The effects of grain orientation and anatomy on the preservation treatment of wood by diffusion method. M.Sc. Engineering Thesis. University of London, 80p.

Owoyemi JM. 2000. Resistance of Gmelina arborea (Roxb) treated with some wood Preservatives to subterranean termites, $35-45$.

Roger EG, Harry NH, Grady HG. 2006. Subterranean termites. Texas Agricultural Extension Service. The Texas A and M University system.http://insect.tamu.edu/ extension/bulletin/b6080.html.

Schultz TP, Nicholas DD, Henry WP, Pittman CU, Wipf O, Goodell B. 2005. Review of laboratory and outdoor exposure efficacy results of organic biocide; antioxidant combinations, an initial economic analysis and discussion of a proposed mechanism. Wood and Fibre Science, 37(1); 175-184.

Smyth AJ, Montgomery R. 1962. Soil and Land Use in Central Western Nigeria. Government Printer: Ibadan, Nigeria. 50.

Tagboto S. Townson S. 2001. Antiparasitic properties of medicinal plants and other naturally occurring products. $A d v$. Parasitol., 50: 199-295.

Wenlong AH, Bush FL. 1989. The effect of preservatives on wood samples. Forestry Journal, 7: 35.

Yalinkilic MK. 2000. Improvement of boron immobility in the boratetarted wood and composite materials, Ph.D. Thesis, Kyoto Unv., Japan, p. 151. 